\title{
ОНИЩУк Я.І.
}

\section{НОВІ МАТЕРІАЛИ ДО ВИВЧЕННЯ БОЙОВИХ ДІЙ НА ТЕРИТОРІЇ «БРОДІВСЬКОГО КОТЛА»У ЛИПНІ 1944 р. (ЗА РЕЗУЛЬТАТАМИ АРХІВНИХ ТА ПОЛЬОВИХ ДОСЛІДЖЕНЬ)}

У статті розглядаються події, які проходили в липні 1944 р. у «Бродівському котлі» на території сучасних Бродівського та Золочівського районів Львівської області. В науковий обіг вводяться нові документи з Центрального архіву Міністерства оборони Російської Федерації у м. Подольськ, а також результати польових досліджень. Детально аналізуеться хід бойових дій, участь у них військових підрозділів обидвох воюючих сторін, значення гренадерської дивізії «Галичина» та ін. Розглядаються результати пошукових робіт, які проводить у «Бродівському котлі» Меморіально-пошукове підприємство Львівської обласної ради «Доля».

Ключові слова: Львівсько-Сандомирська операція, «Бродівський котел», 1 Український фрронт, XIII армійський корпус, дивізія «Галичина», бойові дії, підприемство «Доля», пошук, перепоховання.

Постановка проблели та актуальність. ЛьвівськоСандомирська наступальна операція Червоної Армії, зокрема бої у «Бродівському котлі» в липні 1944 р., віднайшли в літературі широке висвітлення. Їм присвячено велику кількість наукової, мемуарної та науково-популярної літератури $[1 ; 2$, с. 454-458; 4, c. 249-254; 7 та ін.]. Це пов'язано із тим, що в результаті добре спланованої й технічно забезпеченої операції сили 1 Українського фронту оточили в районі Броди-Золочів частини XIII корпусу 4 танкової армії Вермахту. Особлива увага приділена участі в боях та розгрому 14 гренадерської дивізії Вафрфен-СС «Галичина» («14. Waffen-Grenadier-Division der SS»), створення якої в радянській та сучасній російській історіографії завжди

Онищук Ярослав Іванович, кандидат історичних наук, доцент кафедри археології та спеціальних галузей історичної науки, Львівський національний університет імені Івана Франка, м. Львів.

(c) Онищук Я.I., 2017 
розглядалося вкрай негативно. Висвітлення цих подій часто здійснювалося через призму ідеологічних стереотипів, а багато фрактів або замовчувалося, або свідомо перекручувалося.

Таким чином, актуальність проблеми полягає не тільки в тому, що в результаті оточення у «Бродівському котлі» великого угруповання німецьких військ став можливий подальший успішний наступ Червоної Армії, але й в детальному аналізі ситуації, яка склалася тут у липні 1944 р., об'єктивній оцінці успіхів та прорахунків військового командування двох воюючих сторін.

Метою дослідження є введення в науковий обіг нових документів 3 фондів Центрального архіву Міністерства оборони Російської Федерації у м. Подольськ (далі ЦАМО РФ)* про події у "Бродівському котлі», а також результатів польових досліджень, які з 2007 р. на місцях бойових дій проводить Меморіально-пошукове підприємство «Доля».

Виклад основного митеріалу. Підготовка ЛьвівськоСандомирської наступальної операції була ретельно спланована командуванням Червоної Армії. Як відомо, перед початком наступу 1-й Український фрронт був одним із найбільш боєздатних оперативних фрормувань, маючи станом на 1 липня 1944 р.в своєму складі дві гвардійські, чотири загальновійськові, три танкові, одну повітряну армії, а також дві кінно-механізовані групи. Натомість в німецький XIII армійський корпус на той час входило 4 піхотні дивізії (в тому числі дивізія «Галичина») та корпусна група «Ц» (залишки 183, 217 і 339 піхотних дивізій). Як резерв у найближчому тилу розташовувалися III і XXXXVIII танкові корпуси, однак реально в бойових діях "Бродівського котла" брали участь лише частини 8 танкової, 349 і 357 піхотних дивізій.

* Дослідження в ЦАМО РФ проводились за сприянням Всеукраїнської громадської організації «Союз - Народна Пам’ять» (м. Київ). 
Згідно з планом Ставки Верховного Головнокомандування удари Червоної Армї мали бути завдані одночасно 3-під Тернополя на Львів у центрі та 3 району Луцька на Раву-Руську на правому фрланзі. 13 липня 1944 р. на Рава-Руському напрямку перейшли у наступ передові батальйони 3 гвардійської та 13 армій. На центральному відтинку 14 липня розпочали наступ частини 60 і 38 армї $[1$, с. $9 ; 7$, с. 7$]$.

Основні події відбувалися на Львівському напрямі в районі міст Броди-Золочів. В бойових донесеннях 7 гвардійського танкового корпусу (3 гвардійська танкова армія) зазначалося: «К началу Львовской операции сложилась следующая обстановка: противник, потерпев поражение весной 1944 г., поспешно отошел в западном направлении и ведя сдерживающие бои на рубеже БродыТарнополь, строил оборонительный рубеж на линии обороны 1915-1916 гг., используя естественные преграды p. Серет и р. Стрыпа. К началу апреля 1944 г. противник закрепился на рубежах: Броды, Маркополь, Езерна, Козлов и далее на юг по западном берегу р. Стрыпа... К началу операции оборона противника состояла из трёх оборонительных линий с широко развитой сетью траншей и окопов полной профили каждой линии...»* [8, арк. 1].

Розташовані на Львівському напрямку сили РСЧА значно переважали противника за кількістю. Наприклад, до складу 7 гвардійського танкового корпусу входили три гв. танкові (54-56) і 23-тя гв. мотострілецька бригади; 467 гв. окремий мінометний, 287 гв. зенітний артилерійський, 312 гв. винищувальний протитанковий артилерійський, 1419 середній самохідний артилерійський і 702 легкий самохідний артилерійський полки; 440 i 108 гв. окремі мінометні дивізіони; 4 гв. окремий мотоциклетний і 121 гв. окремий саперний батальйони; 156 гв. окремий батальйон зв'язку i 104 окрема рота хімічного захисту.

\footnotetext{
* Тут і надалі цитати подані мовою оригіналу.
} 
3 протилежного боку фронт прикривали частини 349 i 357 піхотних дивізій вермахту. Тактичний резерв в складі 349 саперного батальйону розташовувався в районі с. Лукавець, 349 запасний і фузелерський батальйони - в районі Кругова і підрозділи 913 піхотного полку - біля Перепельників. В оперативному резерві німецького командування знаходилася 8 танкова дивізія III танкового корпусу (кількістю до 80 танків), яка дислокувалася між Сасовом і Золочевом [8, арк. 2].

Ще 28 червня 1944 р. за наказом командувача групою «Північна Україна» генерал-фельдмаршала Вальтера Моделя до складу XIII армійського корпусу була введена 14 гренадерська дивізія «Галичина». Ї̈̈ завданням було розбудувати другу лінію оборони довжиною 36 км вздовж лівого берега р. Стир (орієнтовно між селами Жарків та Монастирок Бродівського р-ну Львівської області). 18 липня 1944 р. в результаті оточення XIII армійського корпусу частини дивізї окремими підрозділами були введені в бій на передньому краї оборони. Як згадував у своїх мемуарах начальник штабу «Галичини» майор В.Д. Гайке: «Тепер з дивізією сталося те, чого ми найбільше боялися: ï кидаеться у найгрізніші бої поодинокими полками, а не як одну цілу одиницю» [3, с. 75].

Для розгрому угруповання німецьких військ у «Бродівському котлі» командування 1 Українським фронтом прийняло рішення додатково ввести в бій 1 гвардійську танкову армію, кінно-механізовану групу генерала В.К. Баранова і частину військ 13 армії [7, с. 9]. Згідно з бойовими донесеннями 322 дивізії 1 стрілецького корпусу (60-та армія) в $14.00 \quad 17.07 .1944$ р. 1089 полк зайняв Княже, 1087 полк в цей самий час оволодів Ясенівцями, однак зустрів сильний опір німецької піхоти i танків на західній околиці Ляцьке (зараз с. Червоне Золочівського р-ну Львівської обл.). «Подтянув артилерию, перегруппировавшись, 1087 стрелковый полк во взаимодействии с 4 СУ мм [самоходными установками калибра 155 мм. - Я.О.] 1885 самоходного полка, 7 танками 59 танкового полка в 12.00 перешёл в 
наступление. После 4-х часового боя 1087 сп. к 1.00 18.07.44 овладел Лацке. 18.07.44 1089 сп., не имея перед собой противника, выполнив задачу дня, занял оборону на рубеже Борткув [с. Бортків Золочівського р-ну] выс. 256.0...» [12, арк. 57].

Таким чином, станом на 18 липня 1944 р. частинам XIII армійського корпусу було перекрито шлях відступу на південь i завершено їх оточення. Наступ Червоної Армї на східній ділянці фронту німецькому командуванню вдавалося деякий час стримувати, насамперед завдяки введення в бій резерву - 14-ї дивізії «Галичина». Ї̈̈ головне завдання полягало в перекритті долин між селами Сасів і Ясенів та недопущення ворога в розташовані у цій місцевості лісисті терени [3, с. 78]. Лінія оборони «Галичини» пролягала через села Пеняки, ГутаПеняцька, Гута Верхобузька, Майдан Пеняцький, Суходоли. Як згадував В.Д. Гайке: «Наші втрати великі... Введення в дію великого числа большевицьких реактивних мінометів («катюш») спричиняє велике спустошення і впливає вирішально на мораль вояків... Жорстокі бої розгортаються за село і замок Підгірці, положені на панівній висоті... Вони кількакратно переходять з рук до рук. Важкі бої йдуть під Кадовбицями [Кадлубиська - зараз с. Лучківці] і Цішками. Ворожі танки досягають уже Олеська...» [3, с. 85-86].

У такій ситуації в районі Підгірців [13, s. 42], за іншими даними, в селі Кути [6, с. 145], було залишено польовий дивізійний госпіталь 3400 раненими вояками. В лісах між селами Гавареччина і Волуйки були покинуті дивізійні обози. Позбувшись важкого спорядження i техніки, підрозділи «Галичини» поступово відходять у район Білого Каменя, звідки готувався прорив 3 котла частин XIII армійського корпусу.

Замкнення Червоною Армією «Бродівського котла» 3 півночі та північного сходу забезпечувала 172 дивізія 102 стрілецького корпусу (13-та армія) в складі 388, 514 і 747 полків, а також прикріпленого до неї окремого штрафного батальйону. Їм протистояли залишки 
361 піхотної дивізії вермахту під командуванням генералмайора Г. Ліндеманна. Згідно 3 «Журналом бойових дій 388 стрілецького полку...», який діяв на основному напрямі атаки, «19.07.1944 г. полк овладел Рожнюв [с. Ражнів Бродівського р-ну. - Я.О.] ... Особенно жестоко оборонял противник Соколувка [с. Соколівка Буського р-ну. - Я.О.], однако в 22.00 19.07.1944 г. подразделения полка боем овладели Соколувка, захватили трофеи и нанесли потери в живой силе и технике противника» [10, арк. 43].

Запеклі бої проходили за населені пункти Олесько і Юськовичі (зараз с. Йосипівка Буського р-ну). За активної підтримки авіації та різних родів важкої зброї о 17.15 20.07 .44 р. 3-й батальйон 388 полку зайняв північну окраїну Олеська, а в 5.0021 липня 1-й батальйон оволодів Юськовичами. В результаті боїв за Олесько 388 стрілецький полк захопив трофеї у кількості 16 вантажних і 2 легкові автомашини, 1 складу інженерного майна, 1 складу боєприпасів, 4 бронетранспортери та 6 полонених [10, арк. 44].

«В 7.15 ч. 21.7.44 г. 2 стр. батальон вышел за село Олеско и стремительно продвигается вперёд в напр. Волуйки. В 12.00 подразделение полка, преследуя противника, овладели с. Волуйки, где взяли 2-х пленных и трофреи:

1. Автомашин - 300 шт.

2. Повозок с военным грузом - 200 шт.

3. Мотоциклов - 40 шт.

4. Орудий разных калибров - 30 шт.

5. Велосипедов - 50 шт.

6. Машинок пишуших - 4 шт.

7. Раций - 2 шт. и другие» [10, арк. 44].

Виходячи із вищеописаного можемо припустити, що здобиччю 388 стрілецького полку стали обози дивізї "Галичина", які були залишені у лісі між селами Волуйки i Гавареччиною. Очевидно, до цієї кількості трофреїв (насамперед автомашин) також було зараховано автомобільну техніку, яку дивізійні та вермахтівські частини через нестачу пального, механічні поломки, бойові пошкодження та ін. залишили на марші, 
рухаючись з Олеська по старій польовій дорозі попри Теребежі, Волуйки, Підлисся на Білий Камінь Учасник боїв П. Силенко, змальовуючи загальну картину хаосу, писав: «Більшість недобитків, виснажених зусиллям останніх трьох діб, разом з легко раненими гуртувалися в лісі Гавареччина при обозах... Всі дороги, що вели в напрямі на Білий Камінь, були... так загачені всякими колонами, що треба було чекати на можливість вирушити 3 лісу.... Всі шляхи і поля були повні вогню, палаючих машин і возів і були встелені людськими й кінськими трупами» [6, с. 145].

Частини розгромленого XIII армійського корпусу станом на 20.07.1944 р. скупчилися в районі сіл Білий Камінь-Почапи 3 наміром прориву з оточення. За даними Управління 15 стрілецького корпусу (60-та армія), військами РСЧА в «Бродівському котлі» були замкнені залишки 149, 361, 383 піхотних дивізій, 14 дивізії «Галичина», корпусної групи «Ц», а також 8 танкової армї̈» [11, арк. 5]. Цього ж дня німецьке командування зробило спробу із зовні розблокувати затиснуті в кільці частини, ударивши зі сторони сіл Ремезівців-СновичіРиків (зараз с. Поляни Золочівського р-ну). Ударну групу складали 2 батальйони піхоти 254 дивізії та 20 одиниць бронетехніки I танкової армії [11, арк. 5]. Спроба, однак, виявилась безуспішною.

Згідно з даними штабу 322 стрілецької дивізії $15 \mathrm{CK}$ в 19.0020 липня 1944 р. близько 800 солдатів вермахту за підтримки 14 танків пішли на прорив у районі Бонишин-Золочів. Інша група кількістю майже 500 осіб спробувала штурмувати позиції 1089 стрілецького полку 322 дивізії північніше с. Княже. Артилерійським i кулеметним вогнем наступ було зупинено, при цьому на полі бою залишилося до 200 убитих і ранених, в полон потрапило 98 чоловік. Така ж доля спіткала близько 250 військово-службовців, в основному дивізійників, які вночі намагалися вирватися 3 оточення в районі станції Скварява. В результаті інтенсивного бою загинуло до 120 чоловік, в полон потрапили близько 100 осіб [12, арк. 58]. 
21 липня впродовж дня оточені групами від 400 до 1000 чоловік близько 10 разів намагалися вийти 3 котла. Згідно 3 інформацією штабу 322 дивізї противник залишив убитими до 2500 чоловік, в полон потрапило до 600 солдатів та офіцерів [12, арк. 58]. Навіть якщо зважити на те, що в бойових донесеннях Червоної Армії дані про втрати ворога часто завищували, а свої, навпаки, применшували, події, що відбувалися в цей час у «Бродівському котлі», вражають своєю трагічністю та кількістю жертв з обидвох сторін.

«22.7.44 г. в 3.00 колонна противника до 800 солдат развернутой цепью в 6 рядов с криком «Ура» бросилась на прорыв в районе 2-го стрелкового батальона и одной из 45 мм батарей. Несмотря на сильный артиллерийский огонь, группе противника до 500 человек удалось прорваться через боевые порядки пехоты и выйти на ОП артиллерии. Артиллеристы не уходили с ОП, а в упор расстреливали противника. На ОП 45 батареи немцы цеплялись за стволы пушек. Много немцев было разорвано прямыми выстрелами с пушек. На ОП артиллерии доходило до рукопашной схватки. Артиллеристы комбата Иванова гильзами отбивались от противника, а с огневой не уходили» [12, арк. 59].

Окрім великого числа трофеїв і полонених, захоплених частинами 322 стрілецької дивізії, в полон також потрапив командуючий XIII армійського корпусу генерал А. Гаудppe із своїм штабом. У бойовому донесенні № 177 ця подія описана так: «23.7.44 кольцо вокруг окруженной группировки противника сжалось. Противник оказывал упорное сопротивление в лесу, что севернее Княже. В 7.00 23.7.44 одна стрелковая рота с группой артиллеристов атаковали лес. Вследствие стремительной атаки сопротивление противника прекратилось. В этом лесу подразделением 1089 стрелкового полка был захвачен в плен командир 13 Армейского корпуса генерал-лейтенант от инфантерии Гауффре со своим штабом. Таким образом, ликвидация окруженной группировки противника закончилась полностью 23.7.1944 г.» [12, арк. 59]. 
Слід зазначити, що в деяких дослідженнях дата ліквідації «Бродівського котла» та захоплення в полон генерала Гауфрфе подається на день раніше - 22 липня [7, с. 9]. Зокрема, в мемуарах командуючого 1 Українським фрронтом I.C. Конева зазначалося: «К исходу 22 июля бродская группировка врага прекратила свое существование. Советские войска уничтожили более 38 тыс. немцев, захватили большие трофеи, взяли в плен 17 тыс. солдат и офицеров, в том числе командира 13-го армейского корпуса генерала Гауфоре с его штабом, а также командиров дивизий генералов Линдемана и Недтвига» [4, с. 254]. Взятий в полон командуючий XIII корпусом загинув цього ж дня, підірвавшись на міні під час транспортування у тил.

Про кількість захоплених трофеїв у період ЛьвівськоСандомирської операції свідчать звіти про діяльність тилів військових частин, зокрема 102 стрілецького корпусу. У них говориться, що з 13 до 21 липня 1944 р. трофрейні команди займалися лише підбором залишеного на полі бою озброєння Червоної Армії, оскільки кількість покинутого німцями майна була незначною. «В период с 21 по 30 июля 1944 г. войска 102-го стрелкового корпуса с боями прошли большой путь по освобожденной территории Западной Украины и Польши и к 1 августа вышли к р. Висла... В указанный период частями корпуса в районах Белого Камня, Каменка-Струмилова, Перемышля, Дембы и др. захвачены большие трофеи противника: бронетранспортеры, автомашины, пушки, боеприпасы, продфураж и прочее имущество, которые частично были использованы частями по своему прямому назначению, а другая часть трофеев сдана на армейские трофрейные склады» [9, арк. 31-32]. Очевидно, що більшість військового майна було підібрано саме в «Бродівському котлі» після розгрому оточених в ньому німецьких частин.

Кровопролитні бої у липні 1944 р. в районі БродиЗолочів завдали великі людські втрати. Тому завдання сучасних дослідників полягає як в об'єктивному 
висвітленні подій радянсько-німецької війни, так i в пошуку полеглих на основі методики польових археологічних досліджень. Це дасть можливість не тільки отримати нові матеріали, але й віднайти i належно поховати останки загиблих військовослужбовців обидвох воюючих сторін. На сьогодні це завдання $е$ особливо актуальним. Воно викликане тим, що в результаті діяльності т.зв. «чорних копачів» військові могили часто руйнуються, а знайдені у них предмети потрапляють на «чорний» ринок. Зазначене явище $е$ не тільки фрактом мародерства, але й подекуди утруднюе визначення приналежності загиблого до воюючої сторони через відсутність супровідного матеріалу. Ще однією важливою проблемою $є$ ідентифікація загиблих. На відміну від військовослужбовців вермахту (в тому числі й дивізійників), які в обов'язковому порядку носили розпізнавальні жетони - «erkennungsmarke», солдати Червоної Армії у цей період війни не мали жодних ідентифрікаторів. Паперові червоноармійські книжки, як правило, не зберігаються у грунті, а тому встановлення осіб загиблих у більшості випадків не є можливим.

З 2007 року пошуково-ексгумаційними дослідженнями на територї «Бродівського котла» займається Комунальне підприємство Львівської обласної ради 3 питань здійснення пошуку поховань учасників національновизвольних змагань та жертв воєн, депортацій i політичних репресій «Доля». За час своєї діяльності його працівниками було віднайдено та перепоховано останки близько 70 військовослужбовців Червоної Армії та дивізії «Галичина»". В більшості випадків вони лежать в засипаних ямах від розривів боєприпасів, окопах, бліндажах і до сьогодні вважаються безвісті пропалими.

* Пошук, ексгумацію та перепоховання солдатів вермахту згідно 3 міжнародною угодою проводить представництво Німецької народної спілки по догляду за військовими могилами (Фольксбунд) в Україні ПП «Гарант» $з$ м. Жовква. 
Могили солдатів воюючих сторін часто трапляються на місцях боїв в околиці сіл Кругів, Верхобуж, Колтів, Білий Камінь, Черемошня, Почапи, Гончарівка, Бонишин та ін. Золочівського району Львівської області. Оскільки результати досліджень поховань вояків дивізії «Галичина» вже публікувалися [5, с. 419-424], в даному випадку більше уваги звернемо на вивчення санітарних захоронень червоноармійців. У 2009 р. одне із таких місць було виявлено біля с. Почапи. Загиблий лежав на глибині 0,8 м від сучасної поверхні у вирві від вибуху боєприпасу. Супровідний матеріал складався 3 кількох гудзиків від штанів, чотирьох металевих рамочних пряжок, алюмініевої ложки та 10 набоїв кал. 7,62×25 мм до стрілецької зброї систем ТТ-ППШ. Дослідження остеологічних залишків засвідчило наявність механічних пошкоджень окремих кісток скелета, спричинених, ймовірно, осколковим пораненням.

Два людських останки виявлені у 2011 р. в лісових масивах на околиці сіл Черемошня та між Почапами i Гончарівкою. В першому випадку військовослужбовець знаходився у ямі на глибині 0,6 м від сучасної поверхні. Положення скелета, а також пошкодження нижніх кінцівок вказує, що людина могла загинути від розриву боєприпасу (мінометна міна, артилерійський снаряд). Супутній матеріал у вигляді солдатського шолома зразка СШ-40, набоїв до гвинтівки с-ми Мосіна кал. 7,62Х54 мм, фррагментів поясного ременя засвідчуе його приналежність до РСЧА. У другому - убитий лежав в одиночному окопі на глибині 0,8 м. Поруч знайдено залишки саперної лопатки, рамкову пряжку від ременя та кілька гудзиків від гімнастерки із п'ятикутними зірочками.

Цікаві результати були отримані у польовому сезоні 2012 р. Зокрема, на південній околиці села Колтів, на схилах пагорба, що домінуе над навколишньою місцевістю, в різних місцях виявлено останки п’ятьох червоноармійців. Вивчення супутніх знахідок дозволяє стверджувати, що солдати окрім стандартних набоїв для стрільби із гвинтівки с-ми Мосіна використовували 
патрони до авіаційного кулемета ШКАС калібру 7,62 мм 3 бронебійними та розривними кулями. Як відомо, вони були заборонені міжнародними конвенціями для ведення вогню по живій силі.

Під час пошукових досліджень біля с. Стоянів Радехівського району Львівської області виявлено кілька масових захоронень періоду липня 1944 р. Ця територія належала до північної зони прориву частин Червоної Арміі. Згідно з інфрормацією місцевих жителів, на околиці села в цей час розташовувався радянський польовий госпіталь. Роботами, проведеними КП ЛОР «Доля» у 2012-2013 pp., в трьох ямах було віднайдено останки 22 червоноармійців, які входили до складу 121 Гомельської гвардійської дивізії 13 Армії.

У 2014 р. санітарні поховання військовослужбовців РСЧА вдалося віднайти у селах Гаї, Боратин Бродівського, Колтів та Червоне Золочівського р-нів. В Гаях могила знаходилася в саду місцевої жительки Гарасимчук Ю.О. Загиблий лежав на глибині 0,9 м від сучасної поверхні на спині у випростаному положенні. Супровідний матеріал складався із залишків шкіряного ременя від штанів, кількох гудзиків від гімнастерки, а також ленд-лізових черевиків 3 кованими підошвами. У лісі біля Боратина захоронення виявили шукачі за військовими трофеями. Тіло убитого червоноармійця було злегка прикопано у бруствері стрілецького окопу. Поруч знайдено уламок алюмінієвої ложки, набої до стрілецької зброї с-м Мосіна та ТТ-ППШ, фррагменти шерстяної тканини від одягу, а також залишки черевиків з кованою підошвою ленд-лізового походження. У Колтові, в різних місцях, знайдено одиночні захоронення 3 солдатів. Могила одного із них була на пасовищі неподалік сільської церкви, праворуч дороги сполученням КолтівВерхобуж. Супровідний матеріал складався із малої піхотної лопатки зразка 1944 р., двох поясних пряжок рамкового типу, двох гудзиків від штанів, чотирьох набоїв до зброї ТТ-ППШ кал. 7,62×25 мм, а також фррагмента значка відмінника програми військово-спортивного 
комплексу ГТО («Готов к труду и обороне»). В с. Червоне останки загиблого червоноармійця виявлено неподалік меморіального кладовища вояків дивізії «Галичина». Він лежав горілиць у випростаному положенні, на глибині 0,3 м від сучасної поверхні. 3 особистих предметів збереглися гудзики від гімнастерки, набої до зброї систем ТТ-ППШ, а також польська монета номіналом 50 грошей 1923 року випуску.

Під час пошукових робіт, проведених у 2015 р. в околиці с. Колтів, натраплено ще на два санітарні поховання. В першому випадку могилу відкрито на території лісового зрубу, праворуч дороги Колтів-Сасів. Тіло було кинуте у вирву від розриву боєприпасу. Цілісність скелета порушена, мабуть, дикими тваринами. Супровідний матеріал складався із залишків взуття (ймовірно, черевиків), набоїв до ППШ-ППС і корпуса деактивованої гранати Ф-1. В другому випадку поховання також знайдено в лісі, праворуч дороги КолтівКругів. На глибині 0,9 м від сучасної поверхні виявлено останки людини, який лежав на спині головою на південь. Скелет зберігся в цілісному анатомічному положенні. І3 супровідного матеріалу виявлено стальний шолом СШ-40, алюмініевий казанок зразка 1935 р., а також залишки сильно зношених чобіт.

Характер вищеописаних військових могил дозволяє стверджувати, що в даному випадку захороненням загиблих військовослужбовців займалися не штатні похоронні команди, а місцеве населення. Часті знахідки розрізнених кісткових залишків у верстві лісового покриву свідчать, що тіла багатьох загиблих після закінчення бойових дій так i залишилися лежати незакопаними і були пошматовані дикими звірами.

Висновки. Отже, нові матеріали, отримані в результаті архівних та польових пошукових досліджень, вказують на складність ситуації, яка виникла в районі Броди-Золочів у липні 1944 р. Намагання радянського командування в найкоротші терміни блокувати i завершити розгром німецьких частин у «Бродівському котлі», а 3 іншого 
боку - за всяку ціну вирватися з оточення, призвели до великих людських втрат. Попри це, в результаті успішно проведеної операції сили РСЧА змогли зайняти Львів і вийти на західний кордон України.

1. Бродовский котел: воспоминания, очерки, документы / Сост. Вербинский М.В., Самарин Б.В. Львов: Каменяр, 1974. - 271 с.

2. Великая Отечественная война 1941-1945 годов. В 12 т. - М.: Кучково поле, 2012. - Т. - 864 с., 22 л. ил.

3. Гайке В.-Д. Українська дивізія «Галичина». Історія формування і бойових дій у 1943-1945 роках/ В.Д. Гайке. - Торонто-Париж-Мюнхен: Братство кол. вояків 1-ї Української дивізії УПА, 1970. - 274 с.

4. Конев И.С. Записки командующего фрронтом / И.С. Конев. - М.: Олма-Пресс, 2003. - 608 с., ил.

5. Онищук Я., Шеремета С. Дослідження поховань вояків дивізії «Галичина» на території «Бродівського котла» / Я. Онищук, С. Шеремета // Українська дивізія «Галичина» (Львівщина): історія, спогади, світлини / упоряд.: І. Іваньков, М. Романюк. - Львів: Духовна вісь, 2016. - С. 419-424.

6. Силенко П. За прорив з оточення //Броди. Збірник статей і нарисів / П. Силенко. - Дрогобич-Львів: Відродження, 2003. - С. 144-153.

7. Суслов Е.Г. Львовско-Сандомирская наступательная операция Советской армии / Е.Г. Суслов. К.: Знання, 1984. - 16 с.

8. Центральный архив Министерства обороны Российской Федерации (далі - ЦАМО РФ). - Ф. 315, оп. 4440, спр. 235.

9. ЦАМО РФ. Ф. 361, оп. 251087 с, спр. 3.

10. ЦАМО РФ. Ф. 388 сп, оп. 145607 с, спр. 2.

11. ЦАМО РФ. Ф. 846, оп. 1, спр. 127.

12. ЦАМО РФ. Ф. 1635, оп. 1, спр. 130.

13. Michelis R. 14. Waffen Grenadier Division der SS (Ukrainische Nr. 1) «Galiyien» / R. Michelis. Warszawa: Militaria, 2008. - 66 s. 
Надійшла до редколегії 07.02.2017 p.

Рецензент: Л.П. Кривизюк, кандидат історичних наук, доцент, провідний науковий співробітник Наукового центру Сухопутних військ,Національна академія сухопутних військ імені гетьмана Петра Сагайдачного, м. Львів.

\section{Онищук Я.И.}

\section{НОВЫЕ МАТЕРИАЛЫ К ИЗУЧЕНИЮ БОЕВЫХ} ДЕЙСТВИЙ НА ТЕРРИТОРИИ «БРОДОВСКОГО КОТЛА» В ИЮЛЕ 1944 Г. (ПО РЕЗУЛЬТАТАМ АРХИВНЫХ И ПОЛЕВЫХ ИССЛЕДОВАНИЙ)

В статье рассматриваются события, которые проходили в июле 1944 г. в «Бродовском котле» на территории современных Бродовского и Золочевского районов Львовской области. В научный оборот вводятся новые документы из Центрального архива Министерства обороны Российской Федерации в г. Подольск, а также результаты полевых исследований. Подробно анализируется ход боевых действий, участие в них военных подразделений обоих воюющих сторон, значение гренадерской дивизии "Галичина» и др. Рассматриваются результаты поисковых работ, проводимых в «Бродовском котле» Мемориальнопоисковым предприятием Львовского областного совета «Доля».

Ключевые слова: Львовско-Сандомирская операция, «Бродовский котел», 1 Украинский фрронт, XIII армейский корпус, дивизия «Галичина», боевые действия, предприятие «Доля», поиск, перезахоронение.

\section{Onyshchuk J.}

NEW MATERIALS FOR LEARNING WARFARE ON THE TERRITORY «BRODY CAULDRON» IN JULY 1944 (BASED ON ARCHIVAL AND FIELD RESEARCH)

The article dealt with the events that took place in July 1944 in the "Brody Cauldron», on the territory of modern Brodyand Zolochiv raion, Lviv Oblast. In the scientific use is introduced a new documents from the Central Archives of the Ministry of Defence of the Russian Federation in the city of Podolsk, and also the results of field research.

There are detailed analysis of the fighting, their participation in military units of both warring parties mentioned Grenadier Division "Galicia» and others. The examination of the results of exploration work conducted in "Brody Cauldron» by Memorial Searching company «Dolya».

Keywords: Lvov-Sandomierz operation, «Brody cauldron», 1st Ukrainian front, XIII army corps, division "Galicia», the fighting, the company «Dolya», searching, reburial. 